\author{
Anna Grzegorczyk ${ }^{1}$ \\ Uniwersytet im. Adama Mickiewicza w Poznaniu
}

\title{
Wpływ św. Teresy z Ávili na życie duchowe Edyty Stein
}

Święci żyją świętymi i pragną świętości².

\section{Karmelitańska paralela}

Wielce zasłużona w humanistyce metoda paraleli pozwala zestawiać rozmaite problemy - i te odległe, i bliskie, w celu uchwycenia między nimi istotowego podobieństwa bądź różnicy. Zagościła ona na dobre w portretowaniu postaci, których obrazy zyskują dzięki niej na wyrazistości - bądź

1 Anna Grzegorczyk - prof. dr hab., filozof, kulturoznawca, kierownik Zakładu Semiotyki Kultury Instytutu Kulturoznawstwa Uniwersytetu im. Adama Mickiewicza, założycielka i dyrektor Centrum Badań im. Edyty Stein, autorka kilkunastu książek, m.in.: Filozofia nieoczekiwanego. Między fenomenologią a hermeneutyka (2002), Filozofia światta Edyty Stein (2004), Ponad kulturami. Uniwersalizm Edyty Stein (2010), Obecność wartości (2010). Redaktorka prac o Edycie Stein: Niewidzialna rzeczywistość. Szkice o filozofii duchowej Edyty Stein (1999) oraz Nowa rzeczywistość. Filozofia i świadectwo Edyty Stein (2000), a także publikacji Centrum Badań im. Edyty Stein (książek z serii Fenomeny i wybranych numerów czasopisma „Zeszyty Naukowe CBES"). Jej obecne zainteresowania skupione są wokół historii mistyki, filozofii rozwoju duchowego i chrześcijańskiego dziedzictwa duchowego. W 2014 roku wydała książkę Humanistyka i obecność.

2 Jan Paweł II, Nie lękajcie się być świętymi, „L'Osservatore Romano” 1999, nr 8, s. 109. 
przez kontrast, bądź podobieństwo. Szczególnie użyteczna jest jako narzędzie analizy duchowego wnętrza portretowanych ${ }^{3}$. Spróbujmy zatem spojrzeć na bohaterki naszego szkicu, uciekając się do tej metody.

Portret biograficzny różnicowany jest przez epoki historyczne, w których przyszło żyć Teresie z Ávili i Edycie Stein. Przedstawmy je zatem na tle czasów im współczesnych.

Teresa z Ávili pochodzi z rodu szlacheckiego (z domieszką krwi żydowskiej, co w pewnym stopniu łączy ją z Edytą Stein - Żydówką), kształci się w domu. W jej biografii można doszukać się konfliktu z inkwizycją (czego dowodzą założone przeciw niej procesy w Kordobie i Sewilli), jak i sympatyzowania z alumbrados, a także z Franciszkiem de Osuna, którego dzieło Trzecie abecadło (Tercer abecedario) znajdzie się na indeksie ksiąg zakazanych. To sympatyzowanie przejawia się w powinowactwie niektórych przemyśleń Teresy z przekonaniami alumbrados, między innymi w położeniu nacisku na bezpośrednie obcowanie z Bogiem, idei wewnętrznego spokoju, idei modlitwy myślnej, osłabieniu roli liturgii, idei bezgrzeszności i eksponowaniu miłości zbawczej. Teresa z Ávili żyje w czasach odrodzenia, które w Hiszpanii przyjmuje postać humanizmu w sferze kultury, ale jednocześnie rozmaitych reakcji na budzącą się świadomość polityczną, społeczną i religijną. W tej ostatniej zachodzą znaczące przemiany związane z rozprzestrzenianiem się reformacji. Próba jej powstrzymania przez inkwizycję przybiera rozmaite formy: ingerencji w rodzące się ruchy religijne (np. alumbrados), procesów sądowych przeciw reformatorom i ich zwolennikom czy wydawania zakazów ingerujących w świeże zdobycze humanistyki (na przykład wydawania indeksów ksiąg zakazanych) ${ }^{4}$. Św. Teresa od Jezusa te burzliwe czasy bardzo przeżywa, rejestrując je w swych dziełach Księga życia i Księga Fundacji i opatrując odpowiednimi, często bardzo osobistymi, komentarzami, które świadczą o wzroście jej świadomości społecznej na przykład w kwestii statusu kobiet ${ }^{5}$. Te kulturotwórcze przemiany, powodujące zamęt duchowy

\footnotetext{
3 Zob. J. Guitton, Metoda paraleli, [w:] J. Guitton, Profile, przeł. A. Borkowska-Szuba, S. Cichowicz, W. Sukiennicka, Warszawa 1973, s. 7-26.

J. I. Adamska O.C.D., Święta Teresa od Jezusa, Poznań 2011.

Por. L. Wrona CM, Terezjańska przyjaźń jako kategoria chrześcijańskiej duchowości, „Życie Konsekrowane" nr 2 (106) 2014, s. 106-122.
} 
w obywatelach XVI-wiecznej Hiszpanii, w formie pośredniej znajdują swój wyraz w meandrycznym rozwoju wewnętrznym Teresy, który kreśli ona w Drodze doskonałości i Twierdzy wewnętrznej - traktatach pełnych spektakularnych opisów duchowej walki. Dzieła te wychodzą jednak nie spod pióra uczonej kobiety, lecz spisane zostają w karmelitańskiej celi na prośbę jej przełożonych.

Edyta Stein wzrasta intelektualnie w burzliwych politycznie i ekonomicznie czasach początku XX wieku (studia uniwersyteckie we Wrocławiu i Getyndze) i w międzywojennej Europie; kształci się i naukowo dojrzewa w ruchu fenomenologicznym, który - jak to określił Józef Tischner - był „wydarzeniem w kulturze”. Jej wielkim osiągnięciem naukowym jest rozprawa doktorska 0 zagadnieniu wczucia ${ }^{6}$, będąca znaczącym wkładem w rozwój nowej metody filozoficznej i ciesząca się uznaniem u jej mistrza i założyciela szkoły fenomenologicznej - Edmunda Husserla. Filozoficznie opracowaną kategorię wczucia kwalifikuje Stein jako tak zwane bezpośrednie doświadczenie, w którym zawiesza się dotychczasową wiedzę na temat poddanego wczuciu fenomenu, doprowadzając tym samym do jego naocznego oglądu i uchwycenia jego istoty (eidos) z uwagi na obiektywnie istniejący świat wartości. Późniejsze dzieła Edyty Stein dookreślają uprawianą przez nią fenomenologię metafizycznie (przede wszystkim jej summa Byt skończony a byt wieczny) i mistycznie (Wiedza krzyża). Na te osiągnięcia i jej naukową karierę kładą się cienie I wojny światowej i rodzącego się nazizmu, wraz z Kryształową Nocą, a następnie II wojny światowej wraz z krematoriami Auschwitz.

Te suche charakterystyki interesujących nas postaci stanowić będą zaczątek rozważań skupionych wokół wybranych węzłów problemowych, takich jak: duchowość, prawda, mądrość i świętość. Aby te węzły ująć, warto przybliżyć najpierw rysy psychofizyczne tych dwóch karmelitanek. W opinii s. Adelgundy „Edyta Stein miała specyficzny sposób mówienia: stanowczy, porywający, pełen osobistego zaangażowania i wewnętrznego poruszenia. Nigdy jeszcze - jak pisze - nie spotkałam człowieka, który by podczas rozmowy potrafił w ten sposób łączyć najgłębszą powagę

E. Stein, O zagadnieniu wczucia, tłum. D. Gierulanka, J. Gierula, Kraków 1988. 
z tak uroczym i uszczęśliwiającym uśmiechem”. A sama filozofka wyzna na swój temat: „Moje koleżanki darzyły mnie miłością i podziwem. Trwałam więc w naiwnym złudzeniu, że wszystko jest we mnie w porządku, co zdarza się często ludziom niewierzącym, wyznającym zasady idealizmu etycznego. Jeśli ktoś zachwyca się tym, co dobre, wierzy, że sam jest już dobry. Uważałam też, że mam prawo potępiać bezlitośnie wszystko, co wydawało mi się negatywne, a więc słabości, pomyłki i błędy innych, czasem nawet w sposób drwiący i ironiczny. Były osoby, które nazywały mnie «uroczo-złośliwą»".

Portret psychofizyczny Edyty Stein rysuje się więc wyraziście: kobieta o silnym charakterze, nieznosząca sprzeciwu, bardzo krytyczna, ambitna, zarozumiała, nawet pyszna, ironiczna, ale o wielkim uroku osobistym, darzona podziwem i miłością.

A Teresa z Ávili? W opinii znawców jej życia „należy podkreślić naturalną, fundamentalną i niespotykanie silną cechę jej osobowości, jaką była zdolność, łatwość i absolutna potrzeba przeżywania swej egzystencji w kluczu relacji międzyosobowych”.

O sobie św. Teresa napisze: „Nie byłam skłonna do szemrania ani do obmowy, nie potrafiłabym, zdaje mi się, życzyć komu bądź czego złego. Nie pożądałam cudzego dobra. Nie pamiętam, by zazdrość, kiedy postała w sercu moim w takim stopniu przynajmniej, by była ciężką obrazą Pana”. Jednakże mimo iż określa siebie jako „bardzo niecnotliwą”, uważa: „Wszyscy też byli ze mnie zadowoleni, bo miałam tę łaskę od Boga, że gdziekolwiek byłam, umiałam podobać się wszystkim i wszędzie byłam bardzo lubiana"10.

W licznych autocharakterystykach Teresa z Ávili przedstawia nam się ponadto jako odważna, wymagająca względem siebie, odporna na trudy życiowe, towarzyska, pełna humoru i przedsiębiorcza.

Psychofizyczne portrety naszych karmelitanek momentami są łudząco podobne i mimo iż oddzielone czterema wiekami, to jakby zaświad-
J. I. Adamska OCD, Sól ziemi, Poznań 1997, s. 153.
E. Stein, Dzieje pewnej rodziny żydowskiej, przeł. J. I. Adamska OCD, Kraków 2000, s. 150.
Cyt. za: L. Wrona CM, Terezjańska przyjaźn jako kategoria chrześcijańskiej duchowości, dz. cyt., s. 111.

10 Św. Teresa od Jezusa, Księga życia, przeł. H. P. Kossowski, Kraków 1997, s. 423 i 123. 
czały o trwałych cechach charakteru, trudnych do historycznej obróbki - cechach budujących silną tożsamość. Te dwie kobiety o mocnych osobowościach, żyjące w oddalonych od siebie czasach, spotkały się na drodze rozwoju duchowego, która jest wspólna, mimo różnic kulturowych czy historycznych.

Zainteresowanie Edyty Stein duchową siostrą, a więc uczonego filozofa - karmelitańską mistyczką, nastąpiło w szczególnym momencie i jakby przypadkowo: podczas wakacji w Bad Bergzabern, latem 1921 roku u przyjaciółki - filozofki Jadwigi Conrad-Martius.

Autentyczność najsłynniejszej bodaj wypowiedzi, która rejestruje początek przemiany Edyty Stein, budzi wiele kontrowersji; dla nas istotny jest jej autobiograficzny tekst: „Sięgnęłam na chybił trafił i wyciągnęłam grubą książkę. Nosiła ona tytuł Życie św. Teresy z Ávili napisane przez nią samą. Zaczęłam czytać, zostałam zaraz pochłonięta lekturą i nie przerwałam, dopóki nie doszłam do końca. Gdy zamykałam książkę, powiedziałam do siebie: «To jest prawda!»"11.

Nie jest to jednak odpowiedź na znaną kwestię Piłata: „A co to jest prawda?", lecz na pytania zadawane właśnie sobie samej, a dotyczące jej dotychczasowych opcji filozoficznych i wyborów życiowych. Bardzo ambitne dociekania naukowe prowadzone pod szyldem fenomenologii i ukończone znakomitym doktoratem na temat metody wczucia, próby dalszych akademickich awansów, a także osobiste pragnienia założenia rodziny - wszystko to zostaje przewartościowane. To tak, jakby Edyta Stein nie tylko usłyszała ewangeliczny głos: „Nawracajcie się”, czyli - „Zmieniajcie myślenie", ale i go posłuchała. Taki właśnie wpływ, porównywalny z głosem, który usłyszał św. Paweł w drodze do Damaszku, miała Teresa z Ávili na Edytę Stein.

By odnaleźć więcej głębszych powinowactw, możemy wstępnie przyjąć, że mistyka jest „spontaniczną fenomenologią”, bliską filozofii opartej na intuicji i doświadczeniu (w tym wczuciu), którą uprawiała Edyta Stein. Fakt, że była ona jednocześnie „uczonym filozofem” i karmelitań-

11 Edyta Stein: Siostra Teresa Benedykta od Krzyża, filozof i karmelitanka, na podstawie wspomnień i listów opracowała Teresa Renata od Ducha Świętego, tłum. M. Kaczmarowski, Paris 1973, s. 61. 
ską mistyczką, nie wymaga komentarza ${ }^{12}$. Jeśli zgodzimy się z tezą o powiązaniu fenomenologii i mistyki, to możemy powiedzieć, że „uczona filozofka” jest w stanie w pełni zrozumieć i zaakceptować dzieła „nieuczonej karmelitanki". I to właśnie owo zrozumienie i pełna akceptacja spowodują spektakularną przemianę Edyty Stein, ogromną metanoię w sferze życia i ducha.

Niech ten wpływ dookreśli badaczka obu świętych, również karmelitanka, s. Janina Immakulata Adamska:

\begin{abstract}
Obie wielkie kobiety - Teresę i Edytę - mimo wielu różnic łączy wielka klarowność duchowa i absolutna niezależność, także realizm, umiar i święty upór. Edyta Stein podczas swego dziesięcioletniego dobijania się do bram Karmelu powtarzała uparcie, że sam Pan zachował dla niej w Karmelu coś, co tylko tam mogła znaleźć. Jego charyzmat widziała jako wstępowanie na górę Karmel, ów przejrzysty szczyt, gdzie człowiek odbija już w sobie czysty obraz Boga. „Jesteśmy w drodze, in via - pisała do s. Adelgundy OSB - gdyż Karmel jest wysoką górą, na którą trzeba wstępować, zaczynając od samego podnóża. Ale iść tą drogą to ogromna łaska". Odczytujemy tu ukłon wdzięcznej uczennicy w stronę mistrza Jana od Krzyża, który swoim nada wyznaczył bezpieczny szlak trudnej wspinaczki na szczyt obcowania z Bogiem ${ }^{13}$.
\end{abstract}

W tej charakterystyce uchwycone zostały najistotniejsze odniesienia Edyty Stein do swej wielkiej nauczycielki, a zarazem także do wielkiego mistrza ich obu - św. Jana od Krzyża, któremu Stein poświęci ostatnie swoje dzieło - Wiedzę Krzyża ${ }^{14}$.

Edyta Stein i Teresa z Ávili, złączone przez odnoszenie się do św. Jana od Krzyża i opisanej przez niego Góry Karmel, wpisują się w tradycję karmelitańską, która stanowi fundament ich powołania. Wielu jest badaczy tej tradycji; dla nas ważne jest takie ujęcie, które bezpośrednio połączy przywołanych tu świętych. S. Adamska pisze:

Góra Karmel jest więc pierwszym źródłem etosu karmelitańskiego związanego symbolicznie i dosłownie ze źródłem proroka Eliasza. Obeznana z opisami Karmelu przez Izajasza, Jeremiasza, Amosa, Nahuma, Pieśń na pieśniami, E. Stein widziała w nim sacrum, miejsce spotkania nieba i ziemi. Każde wstępowanie na górę oznaczało dla niej przekraczanie ludzkiej małości i kruchości, a nawet samego czasu,

12 Szerzej na ten temat piszę w: Filozofia światła Edyty Stein, Poznań 2004.

13 J. I. Adamska OCD, Sól ziemi, dz. cyt., s. 81-82.

14 E. Stein, Wiedza Krzyża, tłum. J. I. Adamska OCD, Kraków 1994. 
by się wedrzeć w wieczne TERAZ Bożej obecności, czyli w modlitwę, będącą - jak mówi - obcowaniem i zjednoczeniem z Bogiem, „najwyższym osiągnięciem, do jakiego uzdolniony jest duch ludzki” ${ }^{15}$.

Jak twierdzi Marian Zawada OCD, istota reguły karmelitańskiej tkwi w tradycji Eliasza, która jest na tyle trwała i uniwersalna, w sensie duchowości, że łączy Stary i Nowy Testament ${ }^{16}$. Ten „prorok proroków”, „prorok gigant” - jak go z kolei określił Jan Paweł II - łączy też i fascynuje obie święte Karmelu, szczególnie poprzez duchowy imperatyw nieustannego stania przed obliczem Boga żywego. Edyta Stein, zadając sobie pytanie, skąd Wielka Teresa czerpała tak jasne zrozumienie potrzeb i wymagań swoich czasów, co kazało jej troszczyć się o sprawy Kościoła, odpowiada:

Właśnie to, że żyła modlitwą, że pozwalała się Panu prowadzić coraz głębiej do swej „twierdzy wewnętrznej”, aż do owej ukrytej komnaty, gdzie mógł jej powiedzieć: „Czas już, abyś sprawy moje wzięła za własne, a Ja będę miał pieczę o twoje!”. Dlatego nie potrafi już niczego innego, jak żarliwością „rozpalić się o chwałę Pana Zastępów" $(1 \mathrm{Krl} \mathrm{19,10)}$ - słowa proroka Eliasza wyryte jako hasło w herbie karmelitanek ${ }^{17}$.

Tę rolę modlitwy czuwania, zakorzenioną w „źródle Eliasza” i kontynuowaną przez św. Teresę od Jezusa, Edyta Stein przejmuje i wciela w swoje życie duchowe. Eliaszowe „stać przed obliczem Pana”, odkryte u reformatorki Karmelu, określi ona jako skuteczne i dla czasów reformacji, i dla burzliwych czasów, w których przyszło jej żyć: „Nasze czasy coraz cięższe, kiedy zawodzi już wszystko inne, ostatni ratunek widzą w tych właśnie ukrytych źródłach"18.

Święty łańcuszek karmelitański: św. Eliasz, św. Teresa z Ávili, św. Jan od Krzyża, św. Teresa Benedykta od Krzyża (Edyta Stein) - splata się przez wspólne im duchowe doświadczenie, rozumienie i wyrażanie.

15 J. I. Adamska OCD, Sól ziemi, dz. cyt., s. 82.

16 Por. M. Zawada OCD, Ogrody rozmodlenia: charyzmat karmelitański, Kraków 2008; Jan XLIV Biskup Jerozolimy, Liber de Iinstitutione Primorum monachorum, ks. I, przeł. J. Zieliński OCD, Kraków 1995 (Biblioteka Duchowości Karmelitańskiej).

17 E. Stein, Modlitwa Kościoła, [w:] E. Stein, Z własnej głębi, t. II, tłum. J. I. Adamska OCD, Kraków 1978, s. 150.

18 E. Stein, Modlitwa Kościoła, dz. cyt., s. 150. 
Edyta Stein na temat świętości wypowie się wprost, pisząc o Katarzynie ze Sieny, Brygidzie Szwedzkiej i Elżbiecie Turyńskiej, proroczo mówiąc o drodze, po której kroczą wybrani przez Boga, bowiem wiemy, że po stuleciach do tych współpatronek Europy dołączy i ona: „I tak przez setki lat powtarza się historia. Trwające na cichej rozmowie z Bogiem dusze mu poświęcone wpływają na bieg wypadków w historii Kościoła, odnawiając oblicze ziemi"19.

Komentując poglądy Edyty Stein na temat omawianych przez nią świętych, s. Immakulata napisze: „Życie świętych najlepiej odczytują święci, gdyż doskonale rozumieją działanie łaski w człowieku. Ci natomiast, którzy jej nie doświadczyli, stoją zakłopotani, a nawet zgorszeni ich pozornie szaloną i ekstrawagancką postawą, inspirowaną przecież przez Ducha Świętego, który prowadzi każdego jego jedyną i niepowtarzalną drogą"20.

\section{Twierdza: wewnętrzna i duchowa}

Metanoia Edyty Stein, która dokonała się, z uwagi na okoliczności zewnętrzne, pod wpływem lektury Księgi życia Teresy z Ávili, jest zatem zasługą i matki Karmelu, i działania Ducha Świętego. Mimo że każda z interesujących nas karmelitanek kroczy ku Bogu drogą , ,jedyną i niepowtarzalną”, to „strukturalne” jej elementy są te same. Stąd w dokonanej przez Edytę Stein analizie Twierdzy wewnętrznej Teresy z Ávili zaakcentowane są współbieżności duchowej trasy prowadzącej na spotkanie z Bogiem. Nazwanie swej analizy Twierdza duchowa ma zatem charakter czysto formalny, gdyż merytorycznie obie twierdze „budowane” są z tych samych "duchowych elementów” i według tych samych „duchowych planów konstrukcyjnych”. Mimo tych podobieństw cel przedstawienia „twierdzy” różni się, jeśli chodzi o motywacje. Jak zaznacza Stein, Teresie z Ávili przyświecają przesłanki religijno-praktyczne, jej natomiast filozoficzno-teoretyczne. Chce bowiem wydobyć „ze stopnia struktury

19 E. Stein, Modlitwa Kościoła, dz. cyt., s. 148.

20 J. I. Adamska OCD, Miłosierdzie, ubóstwo, radość. Rzecz o świętej Elżbiecie Węgierskiej, księżnej turyńskiej, Poznań 2002, s. 123. 
bytu to, co jest właściwe dla bytu ludzkiego”, dla człowieka jako „tworu cielesno-psychiczno-duchowego", w którym dusza lokuje się między ciałem i duchem ${ }^{21}$. Ta szersza teoretyczna perspektywa nie powinna jednak przesłonić wkładu, jaki w rozpoznanie wewnętrznego życia duszy włożyła św. Teresa z Ávili. Jest to wkład zaczerpnięty z własnego doświadczenia mistycznego, doświadczenia homini religiosi. I w tej kwestii spod pióra „uczonej karmelitanki” padają słowa najwyższego uznania:

Takim niezastąpionym świadectwem jest Twierdza wewnętrzna, odznaczająca się bo-
gactwem wewnętrznego doświadczenia świętej Autorki, która osiągnęła najwyższe
stopnie łask mistycznych. Posiadała też niezwykłą umiejętność rozumienia proce-
sów odbywających się w jej wnętrzu. Umiała niewypowiedzianie jasno, plastycz-
nie, a jednocześnie bardzo prawdziwie je przedstawić. Była obdarzona mocą po-
zwalającąjej dojrzeć poszczególne sprawy w ich wewnętrznym całokształcie i ten
całokształt ukazać w swoim dziele ${ }^{22}$.

To plastyczne i prawdziwe ukazanie wnętrza duszy jest tym, co wspólne zarówno dla obu karmelitanek (a zarazem istotowo ujęte w ich rozwoju duchowym), jak i dla każdego poszukującego autentycznie prawdy człowieka.

\section{Bóg}

Przed lekturą św. Teresy z Ávili Edyta Stein poszukiwała usilnie prawdy na drodze dociekań fenomenologicznych. Refleksja filozoficzna stanowiła dla niej jedyną formę modlitwy, a prawda z niej płynąca była niczym Bóg. Po przemianie duchowej następuje znamienne odwrócenie myślenia i życiowych wyborów: to Bóg staje się Prawdą, a ona sama stara się ukierunkować swoją egzystencję na służbę Bogu. Ambicje naukowe zamieniają się w „posługę myślenia”, a znakomita fenomenolożka zaczyna szturmować bramę Karmelu w Kolonii. Jej miłość do nauki zostaje podporządkowana pragnieniu Boga, spotkania Go, wyczuwania Jego Obec-

21 E. Stein, Twierdza duchowa, tłum. J. I. Adamska OCD, Poznań 1998, s. 93.

22 E. Stein, Twierdza duchowa, dz. cyt., s. 93-94. 
ności. Analiza „twierdzy” św. Teresy z Ávili przechodzi w jej autentyczne zdobywanie.

Nietrudno zauważyć, że kierunek, jaki przybrała ta przemiana, wiele zawdzięcza wielkiej reformatorce. To nastawienie na modlitwę, szczególnie modlitwę myślną, trwanie w adoracji Boga, sekretne bycie z Bogiem, radość z cichej samotności jako czasu i przestrzeni dla Najwyższego sprawiają, że Edyta Stein mogłaby wprost za św. Teresą powiedzieć: „Solo Dios basta" i zacytować jej wiersz:

\author{
Nie trwóż się, nie drżyj \\ śród życia dróg - \\ Tu wszystko mija, \\ Trwa tylko Bóg! \\ Cierpliwość przetrwa \\ Dni ziemskich znój. \\ Kto Boga posiadł \\ Ma szczęścia zdrój: \\ Bóg sam wystarcza! 23
}

Po wstąpieniu do Karmelu w Kolonii to przesłanie będzie dla Edyty Stein hasłem przyświecającym każdemu dniu. Również w swej korespondencji wielokrotnie będzie mówić o życiu w celi jako formie rzeczywistego karmelitańskiego zamieszkiwania i duchowego bycia w twierdzy, w której „Bóg sam wystarcza”. Przedstawiając Romanowi Ingardenowi - swemu koledze ze szkoły fenomenologicznej i człowiekowi, którego niegdyś darzyła głębszym uczuciem - obraz życia, jaki wiedzie w klasztorze, pisze: „To tylko taka krótka migawka, żeby nie wyobrażał Pan sobie, że wiodę tu jakiś ponury więzienny żywot. W rzeczywistości wobec nikogo współczucie nie byłoby bardziej nie na miejscu niż wobec mnie. Nie ma człowieka, z którym chciałabym się zamienić. Życie nauczyłam się kochać dopiero od chwili, gdy zrozumiałam, dla jakiej sprawy żyję"24. Powołując się wprost na św. Teresę, pisze - również do Ingardena - o „realnym dzianiu się” w niej życia duchowego, które jest wypełnione Bogiem: „To

${ }^{23}$ Św. Teresa od Jezusa, Dzieła, t. 3, przeł. H. P. Kossowski, Kraków 1995, s. 245.

${ }^{24}$ Spór o prawdę istnienia. Listy Edith Stein do Romana Ingardena, przeł. M. Klentak-Zabłocka, M. Wajs, Kraków 1994, s. 150. 
nieskończony świat, który otwiera się całkiem na nowo, gdy zamiast na zewnątrz, zaczyna się wreszcie żyć do wewnątrz. Wszystkie realne rzeczy, z którymi przedtem miało się do czynienia, stają się przeźroczyste i zaznacza się odczuwalna obecność sił, które wprawiają w ruch i stanowią właściwy fundament"25.

\section{Prawda, która cierpi}

To zjednoczenie z Chrystusem, efekt zdobycia przez Edytę Stein ostatnich mieszkań w „twierdzy”, aż po akt ofiary całopalnej i śmierć męczeńską, zaświadcza, jak blisko stoi ona i u stóp Krzyża, i przy Teresie Wielkiej. To św. Teresa jest bowiem autorką słów, że „prawda, która cierpi, nigdy nie ginie"26. Stwierdzenie to, dalekie od naukowych definicji prawdy, stanie się dla naszej fenomenolożki w pełni przekonujące i filozoficznie, i życiowo. Napisze ona, prawie jako dokument i świadectwo zarazem, Wiedzę Krzyża, w której stwierdzi: „,wiedza Krzyża to uznana prawda, teologia Krzyża - prawda żywa, rzeczywista i działająca; wpada ona w duszę na kształt ziarna, zapuszcza w niej korzenie i wzrasta. Wyciska na duszy znamię, przez nie promieniuje i daje się poznać. Jest to wiedza świętych, a my ją nazywamy wiedzą Krzyża. Ta żywotna forma i moc kształtuje w najgłębszym wnętrzu duszy sposób pojmowania życia, pewien obraz Boga i świata, który wyraża się w pojęciach"27.

Prawda i Krzyż to w ujęciu obu karmelitanek cel ich drogi duchowej i odkupieńczej zarazem. To zwieńczenie ich życiowego i mistycznego doświadczenia. To sens życia, które jest podporządkowane Bogu i drugiemu człowiekowi. To cel wznoszenia się na szczyt Góry Karmel, ku Bytowi Najwyższemu i Prawdzie Jedynej. Stąd Edyta Stein stwierdzi: „Ci, którzy to rozumieją, muszą w imieniu wszystkich wziąć ten Krzyż na siebie”28.

25 Spór o prawdę istnienia..., dz. cyt., s. 193.

26 Św. Teresa od Jezusa, Listy, przeł. J. E. Bielecki, Kraków 2008, s. 809.

27 E. Stein, Wiedza Krzyża, dz. cyt., s. 19-20.

28 Jest to zdanie pojawiające się w różnych wersjach w pismach Edyty Stein, szczególnie w Wiedzy Krzyża; por. J. I. Adamska OCD, Błogosławiona Edyta Stein, Kraków 1988, s. 209-211. 


\section{Mądrość ${ }^{29}$}

Przemiana intelektualna i duchowa, która dokonała się w Edycie Stein między innymi dzięki Teresie z Ávili, zweryfikowała jej poglądy na temat prawdy filozoficznej, jak i przyczyniła się do duchowego rozwoju. Odkrycie Prawdy-Boga - i to w Krzyżu i cierpieniu - miało swe dalsze konsekwencje w położeniu nacisku na kategorię mądrości, która odtąd zyska niezwykłą wagę w filozofii i życiu Edyty Stein. Wiemy, że i ta kategoria nie była obca Teresie Wielkiej. Według niej to doświadczanie, a nie lektura jest tym, co prowadzi do „prawdziwego poznania”. Jak pisze: „Kto doświadczył, rozumie to poniekąd, bo jaśniej tego się wyrazić nie da, tak są ukryte te rzeczy, które się dzieją w tym wewnętrznym zjednoczeniu"30. Bowiem to przez doświadczenie, a nie przez słowa komunikują się ludzie przekraczający siebie wzwyż, w kierunku transcendencji; słowa, obrazy, metafory są jedynie skromnymi środkami oddającymi w ostatnich fazach „mistycznej komunikacji” ten „lot ducha”, środkami - co jest wyraźnie podkreślone - słabo przystającymi do rzeczywistej duchowej sytuacji poznającego. Św. Teresa odnosi się do tego poznania z pokorą; ryzyko ośmieszenia, z którego w pełni zdaje sobie sprawę, nie zatrzymuje jej przed pragnieniem trwania w obecności Boga:

Ale wobec Mądrości nieskończonej, niechaj mi wierzą, że odrobina studiowania pokory i jeden jej akt wart jest więcej niż cała wiedza świata. Nie ma tu miejsca na dysputy, a jedynie należy ze szczerością uznać to, kim jesteśmy, i z prostotą uobecnić się przed Bogiem, który chce, aby dusza oniemiała, jak faktycznie dzieje się to wobec Jego obecności, gdyż Jego Majestat upokarza się tak bardzo, że ją ścierpia przy sobie, pomimo że my jesteśmy tym, kim jesteśmy ${ }^{31}$.

Takie odczytanie przekazu św. Teresy wskazuje właśnie na obecność jako najbardziej przekonującą i wiarygodną formę spotkania człowieka z Bogiem i Boga z człowiekiem. Stąd przekonanie „Solo Dios ba-

29 Por. A. Grzegorczyk, Dwie twarze - jedno oblicze mądrości. Św. Teresa z Àvila i św. Teresa Benedykta od Krzyża (Edyta Stein), [w:] A. Grzegorczyk, Humanistyka i obecność, Poznań 2014.

30 Św. Teresa od Jezusa, Księga życia, dz. cyt., s. 261.

31 Św. Teresa od Jezusa, Księga mojego życia, tłum. D. Wandzioch, Poznań 2007, s. 179. 
sta” - „Tylko Bóg wystarcza” jest przekonaniem doświadczonym, a nie wyspekulowanym.

Termin „mądrość” w dziełach św. Teresy jest zazwyczaj synonimem Boga, Prawdy, Ojca, Kreatora, Dobra, Majestatu, Tego, który Jest i który wiedzie do siebie, który jest Mądrością i do Mądrości prowadzi. Trzeba jednak na drodze doskonałości, przechodząc przez trudy mieszkań twierdzy wewnętrznej, tę Mądrość rozpoznać i skoncentrować się na niej, żyć jak „mądra pszczoła” skupiona na jednym: „na wytwarzaniu miodu”.

Natomiast refleksja mądrościowa Edyty Stein od początku związana była z fenomenologią i to z niej zaczerpnęła ona zarówno kategorię doświadczenia, jak i ukierunkowanie na jego bezpośredniość, gwarantującą dochodzenie do istoty rzeczy(eidos), a także wiązanie tej kategorii z kategorią wczucia. W swej późniejszej drodze filozoficznej i egzystencjalnej Edyta Stein właśnie pod przemożnym wpływem Teresy z Ávili kategorie te uczyni podstawą wiedzy mądrościowej, a za taką przyjmie wiedzę Krzyża.

W kwestii doświadczenia mistycznego św. Teresa Benedykta od Krzyża napisze:

\begin{abstract}
W swym najgłębszym wnętrzu człowiek ma przystęp do Boga, i w takim tylko wypadku wolno mówić o Jego doświadczeniu i poznaniu. „Poczucie obecności Bożej” nazwaliśmy zasadą wszelkiego doświadczenia mistycznego. Jest to zaledwie początek, najniższy stopień mistycznego życia modlitwy. Stąd aż do szczytu „kontemplacji wlanej”, do trwałego zjednoczenia z Bogiem prowadzą różne stopnie i przejścia. W każdym wyższym stopniu Bóg bardziej i głębiej objawia się duszy, która otrzymuje ciągle głębsze i lepsze przenikanie i poznanie Boga, chce na nie odpowiedzieć coraz bardziej totalnym oddaniem siebie ${ }^{32}$.
\end{abstract}

Również w ujęciu ćwiczeń duchowych, niezbędnych dla rozwoju wewnętrznego, Edyta Stein wiele zawdzięcza Teresie Wielkiej. Co prawda studiuje i praktykuje w znacznym zakresie reguły i rady św. Benedykta i św. Ignacego Loyoli, ale wystarczy przywołać choćby jej tekst Sposoby osiagnięcia wewnętrznego uciszenia, aby przekonać się o wyraźnych odniesieniach do autorki Drogi doskonałości. Potwierdza to opracowanie architektury duszy wpisane w twierdzę wewnętrzną czy codzienne praktyki

32 E. Stein, Z własnej głębi, dz. cyt., 185-186. 
świeckie (perfekcyjna organizacja dnia) i religijne (w szczególności modlitwa i Eucharystia) jako mądrościowe „wznoszenie się do sensu bytu”. „Chodzenie w prawdzie”, „czynienie prawdy”, „trzymanie za rękę Pana Boga"- to jej sugestywne określenia, tożsame z terezjańskimi, i zarazem sposoby słowo czynnego bycia w świecie, które nakierowane jest na poznanie uczestniczące i spotkanie Prawdy Jedynej - Boga. Przekierowanie się z szukania prawdy Absolutu na doświadczanie Prawdy-Boga jest właśnie tym krokiem mądrościowym, którym Stein podąża po swej konwersji. Na drodze do Mądrości skupia się na jednym i Jedynym - na doświadczaniu Boga, co według Księgi życia (rozdz. 40) jest jej warunkiem sine qua non. To doświadczanie Boga - przypomnijmy - zdobywa się tylko wtedy, gdy się samemu doświadczy Krzyża. Stąd Stein mocno i z pełnym przekonaniem powie: „Ave Crux, Spes unica”, bo „jedynie niosąc Krzyż, nie umiera się". Mądrość Krzyża - jako najwyższe doświadczanie obecności Boga - uznała też Teresa z Ávili w przytoczonym już sformułowaniu: „Prawda, która cierpi, nigdy nie ginie”.

Analiza pism i dróg życiowych Teresy z Ávili i Edyty Stein pokazuje, iż obie dochodzą do Mądrości, która - według ich przekonań - jest Najwyższą Obecnością i jest jedna. Każda jednak kroczy ku niej nieco odmienną ścieżką, wiodącą przez różne obszary wiedzy i egzystencjalnych doświadczeń. Obie drogi - spontaniczna (nieuczona) i fenomenologiczna (uczona) - bazują na doświadczeniu, które rozumiane jest bądź jako doświadczenie życiowe, bądź jako bezpośredni wgląd. Spotykają się one jednak w doświadczeniu religijnym i mistycznym zarazem. To doświadczenie - jako ćwiczenie w mądrości - uczy skupienia się na jednym (spontanicznie rozumianym jako relacja człowieka do bliźniego i Boga). Natomiast efektem tego skupienia jest scalenie i ocalenie tożsamości oraz wartości najwyższych. Dzięki temu doświadczeniu św. Teresa i Edyta Stein przechodzą przez twierdzę wewnętrzną i duchową zarazem, w której odkrywają jedno oblicze Mądrości - Trójcę Świętą, a relacja miłości między Duchem Świętym, Ojcem i Chrystusem uobecnia się w duszy każdej z nich; oblicze to, kontemplacyjnie zgłębione, uobecnia też wartości transcendentne: Prawdę, Dobro i Miłość.

Drogi Teresy z Ávili i Edyty Stein wiążą się z poznaniem uczestniczącym - uobecniającym; sukcesywnie odkrywana jest w nich prawda, która 
cierpi, zmienia myślenie i jednocześnie przekształca duszę. Jest to prawda Ewangelii, prawda czyniąca, prawda jako dawanie Dobra. Drogi te są wyznaczone przez przyjęcie zaproszenia do Mądrości Chrystusa. Mądrość dla Teresy z Ávili i Edyty Stein - mądrość będąca miłością Boga i do Boga w swej jedni - jest miłością i mądrością ukrzyżowaną. Krzyż nie likwiduje mądrości, on ją niesie - uobecnia. Doświadczenie trudności przybliża i uzdalnia do mądrości. Oblicze Boga-Chrystusa jako prawda jedyna jest zatem ikoną mądrości i Obecności Najwyższej. Przed nim klękają nasze święte, dając wyraz przyjęciu zaproszenia do Mądrości, która jest Prawdą i Bogiem. Przyjęcie tego zaproszenia ujawnia się w świętości, której świadectwem są ich księgi życia. Wedle księgi Teresy z Ávili: „Solo Dios basta", a wedle Edyty Stein, jeśli doświadczymy obecności Chrystusa, nie potrzebny jest żaden naukowy argument.

\section{Kobieta}

Warto wskazać na jeszcze jedno spotkanie dróg obu świętych. Wiedzie ono przez obszar związany z tak zwaną kwestią kobiecą.

„Żadna kobieta nie jest tylko kobietą" - to zdanie jednoznacznie określiło radykalne poglądy Edyty Stein w kwestii kobiet. Radykalne jak na czasy jej współczesne, a nie nasze. Przeczytajmy bowiem do końca jej wypowiedź: „każda [kobieta] odznacza się właściwymi sobie cechami i uzdolnieniami, wcale nie mniejszymi od mężczyzny i może dzięki temu wykonywać pracę artystyczną, naukową i techniczną itd. Uzdolnienia indywidualne mogą zasadniczo kierować się ku każdej dziedzinie, nawet dość odległej specyfice kobiecej i ku zawodom niekobiecym"33.

Jak widzimy, radykalizm ten należy odczytywać na tle początku XX wieku, kiedy niezwykle rzadko kobietom zdarzało się studiować na uniwersytecie (w szczególności dyscypliny humanistyczne). Jak pisze Stein w swym dziele Kobieta - jej zadanie według natury i łaski: „Na przełomie

33 E. Stein, Kobieta - jej zadanie według natury i łaski, tłum. J. I. Adamska OCD, Tczew-Pelplin 1999, s. 16. 
ostatniego stulecia w aspekcie prawnym i politycznym kobiety stały na równi z niepełnoletnimi i niepełnosprawnymi umysłowo" ${ }^{34}$.

Gdy zestawimy te słowa z poglądami panującymi w epoce św. Teresy z Ávili, to zobaczymy, jak długo utrzymywało się przekonanie o ułomności natury kobiecej, wyrażane w stwierdzeniach typu: ,[kobieta] narodziła się po to, aby być poddanąi uległą mężowi. A ponieważ czymś oczywistym jest słabość, ignorancja i marne chęci kobiety, ona winna odnajdywać swą cnotę przy lnie i bawełnie” (mnich augustyński - Luis de León); czy: „,z natury kobieta jest ułomnym zwierzęciem, a zatem jej opinia nie może być pewna. Jej myśl nie jest stała, raczej zmienna i lekka. I jak to potwierdziła nasza matka Ewa, może być okłamywana" (Jean Luis Vives - XVI-wieczny humanista hiszpański). Poglądy tego rodzaju nie dawały większych szans na oddziaływanie kobiet w życiu społecznym i politycznym. Przedstawiano im więc - jak pisze Lidia Wrona CM - „dwie perspektywy rozwoju i zaangażowania społecznego: życie domowe bądź zakonne"35.

Św. Teresa wybrała drogę zakonną nie w pełni przekonana, ze słabą motywacją, ale jako mimo wszystko lepszą od małżeńskiego zniewolenia, które obserwowała „w świecie” i w życiu swej zamężnej siostry. Edyta Stein z kolei, mimo swych feministycznych poglądów, bardzo chciała wyjść za mąż, ale nie udało się jej zrealizować tego pragnienia. Obie odkryły i zrealizowały swe życiowe powołanie w życiu zakonnym: św. Teresa - reformując je, św. Benedykta od Krzyża - całkowicie się mu poddając. Jedna i druga zachowały przy tym swoje poglądy dotyczące partnerstwa kobiety i mężczyzny: ich odrębności z uwagi na naturę, ale równości w człowieczeństwie; odrębności, która wyznacza szereg uzupełniających się funkcji w rodzinie (macierzyństwo i ojcostwo), ale i równości, która wyznaczać im winna te same uprawnienia w rolach społecznych.

Edyta Stein doceniała terezjańskie przeświadczenia w kwestii kobiecej, ale nie czyniła z nich bezpośredniego wsparcia dla swoich. Współbrzmienie poglądów obu świętych bierze się z odniesienia do wspólnego im horyzontu mądrościowego i z oporu wobec niesprawiedliwości różnic

34 E. Stein, Kobieta - jej zadanie według natury i łaski, dz. cyt., s. 139.

35 Cyt. za: L. Wrona CM, Terezjańska przyjaźń jako kategoria chrześcijańskiej duchowości, dz. cyt., s. 109-110. 
społecznych, uprzywilejowujących mężczyznę względem kobiety zarówno w wieku XVI, jak i na początku wieku XX. Wiele podobieństw w tym zakresie może pochodzić też z paraleli charakterologicznej, o której mówiliśmy. Dlatego też dopatrywanie się na przykład genderowego ziarna $\mathrm{w}$ feminizmie Edyty Stein jest według mnie nieporozumieniem ${ }^{36}$. Jej poglądy, historycznie ważne i tak właśnie uwarunkowane, nie powinny być kwalifikowane jako radykalnie feministyczne, wręcz przeciwnie - tonuja one znacznie postulaty wyrażane współcześnie w ramach skrajnej myśli genderowej.

\section{Zakończenie}

Dwie wielkie kobiety, portretowane na różne sposoby, wykazujące duże podobieństwa i mniejsze różnice w sferze ludzkiej egzystencji i rozwoju życia duchowego, fascynowały w przeszłości i fascynują dziś. Wpływ św. Teresy ma już pięciowiekową tradycję. Św. Teresa Benedykta od Krzyża ma w tym zakresie zdecydowanie skromniejsze oddziaływanie. Chciałoby się powiedzieć: czas pokaże, czy będzie równie „wiekowe” i silne. Dla nas ważne i dające do myślenia jest motto, od którego zaczęliśmy naszą refleksję: „Święci żyją świętymi i pragną świętości”.

36 Zob. E. Adamiak, Pytania kobiet, „L'Osservatore Romano” 2014, nr 9: „Kobiety - Kościół - Świat"; por. www.ekai.pl/wydarzenia/temat_dnia/x81655/elzbieta-adamiak-pytania-kobiet/ (7.09.2014). 


\section{Summary}

\section{Saint Teresa of Àvila's influence on Edith Stein's spiritual life}

In Edith Stein's works one can find reflections of some of Saint Teresa of Àvila's ideas. Similarity of their characters can be one clue to explain it, but what's more important - it is their Carmelite spirituality what makes this resemblance. Close parallel between them both can be seen in matters like concept of true, of wisdom, and the issues of woman. Beside historical distance and all biographical differences, Edith Stein and Saint Teresa of Àvila join into Carmelite tradition through spiritual experience, understanding and expression.

Keywords: spiritual development, Carmelite tradition, truth, wisdom, experience, woman, saintness

\section{Wpływ św. Teresy z Ávili na życie duchowe Edyty Stein}

W dziełach Edyty Stein zaznaczają się wyraźnie myśli św. Teresy z Ávili. Zapewne podobieństwo charakterologiczne ma pewne uzasadnienie w tym względzie, jednakże powinowactwa te wynikają przede wszystkim z duchowości karmelitańskiej, w której obie są zakorzenione. Ta bliska paralela widoczna jest przede wszystkim w odniesieniu do takich kategorii jak prawda, mądrość czy kwestia kobieca. Pomimo dystansu historycznego i wielu biograficznych różnic obie święte włączają się w tradycję karmelitańską przez wspólne im duchowe doświadczenie, rozumienie i wyrażanie.

Słowa kluczowe: rozwój duchowy, tradycja karmelitańska, prawda, mądrość, doświadczenie, kobieta, świętość

\section{Bibliografia}

Adamiak E., Pytania Kobiet, „L'Osservatore Romano” 2014, nr 9: „Kobiety - Kościół - Świat"; por. http://ekai.pl/wydarzenia/temat_dnia/x81655/elzbieta-adamiak-pytania-kobiet/ [7.09.2014].

Adamska J. I. (OCD), Błogosławiona Edyta Stein, Kraków 1988.

Adamska J. I. (OCD), Miłosierdzie, ubóstwo, radość. Rzecz o świętej Elżbiecie Węgierskiej, księżnej turyńskiej, Poznań 2002.

Adamska J. I. (OCD), Sól ziemi, Poznań 1997.

Adamska J. I. (OCD), Święta Teresa od Jezusa, Poznań 2011.

Edyta Stein: siostra Teresa Benedykta od Krzyża, filozof $i$ karmelitanka, na podstawie wspomnień i listów oprac. Teresa Renata od Ducha Świętego, przeł. M. Kaczmarowski, Paris 1973. 
Grzegorczyk A., Filozofia swiatta Edyty Stein, Poznań 2004.

Grzegorczyk A., Humanistyka i obecność, Poznań 2014.

Guitton J., Metoda paraleli, [w:] J. Guitton, Profile, przeł. A. Borkowska-Szuba, S. Cichowicz, W. Sukiennicka, Warszawa 1973, s. 7-26.

Jan Paweł II, Nie lękajcie się być świętymi, „L'Osservatore Romano” 1999, nr 8, s. 17-19. Jan XLIV biskup Jerozolimy, Liber de Iinstitutione Primorum monachorum, ks. I, przeł. J. Zieliński OCD, Kraków 1995 (Biblioteka Duchowości Karmelitańskiej).

Spór o prawdę istnienia. Listy Edith Stein do Romana Ingardena, przeł. M. Klentak-Zabłocka, M. Wajs, Kraków 1994.

Stein E., Dzieje pewnej rodziny żydowskiej, przeł. J. I. Adamska OCD, Kraków 2000.

Stein E., Kobieta - jej zadanie według natury i łaski, tłum. J. I. Adamska OCD, TczewPelplin 1999.

Stein E., O zagadnieniu wczucia, tłum. D. Gierulanka, J. Gierula, Kraków 1988.

Stein E., Twierdza duchowa, tłum. J. I. Adamska OCD, Poznań 1998.

Stein E., Wiedza Krzyża, tłum. J. I. Adamska OCD, Kraków 1994.

Stein E., Z własnej głębi, t. II, tłum. J. I. Adamska OCD, Kraków 1978.

Teresa z Ávili św., Dzieła, t. 3, przeł. H. P. Kossowski, Kraków 1995.

Teresa z Ávili św., Księga życia, przeł. H. P. Kossowski, Kraków 1997.

Teresa z Ávili św., Listy, przeł. J. E. Bielecki, Kraków 2008.

Wrona L. (CM), Terezjańska przyjaźń jako kategoria chrześcijańskiej duchowości, „Życie Konsekrowane" 2014, nr 2 (106), s. 106-122.

Zawada M. (OCD), Ogrody rozmodlenia: charyzmat karmelitański, Kraków 2008. 